\title{
Review
}

\section{The Immune System through the Lens of Alcohol Intake and Gut Microbiota}

\author{
Javier Calleja-Conde ${ }^{1,+}+\mathbb{D}$, Victor Echeverry-Alzate ${ }^{1,2,3,+} \mathbb{C}^{-}$, Kora-Mareen Bühler ${ }^{1}$, Pedro Durán-González ${ }^{1}$,

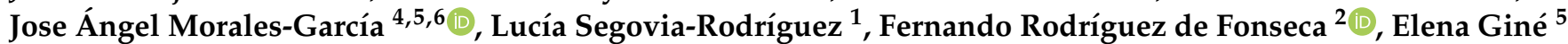 \\ and Jose Antonio López-Moreno ${ }^{1, *}$
}

\section{check for}

updates

Citation: Calleja-Conde, J.; Echeverry-Alzate, V.; Bühler, K.-M.; Durán-González, P.; Morales-García, J.Á.; Segovia-Rodríguez, L.; Rodríguez de Fonseca, F.; Giné, E.; López-Moreno, J.A. The Immune System through the Lens of Alcohol Intake and Gut Microbiota. Int. J. Mol. Sci. 2021, 22, 7485. https://doi.org/ $10.3390 /$ ijms 22147485

Academic Editor: Luigi Casella

Received: 17 June 2021

Accepted: 7 July 2021

Published: 13 July 2021

Publisher's Note: MDPI stays neutral with regard to jurisdictional claims in published maps and institutional affiliations.

Copyright: (c) 2021 by the authors. Licensee MDPI, Basel, Switzerland. This article is an open access article distributed under the terms and conditions of the Creative Commons Attribution (CC BY) license (https:// creativecommons.org/licenses/by/ $4.0 /)$.
1 Departamento de Psicobiología y Metodología en Ciencias del Comportamiento, Facultad de Psicología Universidad Complutense de Madrid, 28223 Madrid, Spain; jcconde@ucm.es (J.C.-C.); echeverry.v@psi.ucm.es (V.E.-A.); kobuhler@psi.ucm.es (K.-M.B.); pduran01@ucm.es (P.D.-G.); luciaseg@ucm.es (L.S.-R.)

2 Unidad Gestión Clínica de Salud Mental, Instituto de Investigación Biomédica de Málaga (IBIMA), Hospital Regional Universitario de Málaga, Malaga University, 29010 Málaga, Spain; fernando.rodriguez@ibima.eu

3 Universidad Nebrija, Campus Madrid-Princesa, 28015 Madrid, Spain

4 Instituto de Investigaciones Biomédicas (CSIC-UAM) “Alberto Sols” (CSIC-UAM), 28029 Madrid, Spain; jmoral06@ucm.es

5 Departamento de Biología Celular, Facultad de Medicina, Universidad Complutense de Madrid, 28040 Madrid, Spain; elena.gine@med.ucm.es

6 Centro de Investigación Biomédica en Red en Enfermedades Neurodegenerativas (CIBERNED), 28031 Madrid, Spain

* Correspondence: jalopezm@psi.ucm.es

$\dagger$ Authors had equal contribution to this work.

Abstract: The human gut is the largest organ with immune function in our body, responsible for regulating the homeostasis of the intestinal barrier. A diverse, complex and dynamic population of microorganisms, called microbiota, which exert a significant impact on the host during homeostasis and disease, supports this role. In fact, intestinal bacteria maintain immune and metabolic homeostasis, protecting our organism against pathogens. The development of numerous inflammatory disorders and infections has been linked to altered gut bacterial composition or dysbiosis. Multiple factors contribute to the establishment of the human gut microbiota. For instance, diet is considered as one of the many drivers in shaping the gut microbiota across the lifetime. By contrast, alcohol is one of the many factors that disrupt the proper functioning of the gut, leading to a disruption of the intestinal barrier integrity that increases the permeability of the mucosa, with the final result of a disrupted mucosal immunity. This damage to the permeability of the intestinal membrane allows bacteria and their components to enter the blood tissue, reaching other organs such as the liver or the brain. Although chronic heavy drinking has harmful effects on the immune system cells at the systemic level, this review focuses on the effect produced on gut, brain and liver, because of their significance in the link between alcohol consumption, gut microbiota and the immune system.

Keywords: alcohol; gut; microbiota; brain; liver; immune system; dysbiosis

\section{Gut Microbiota and Immune System}

The human body contains many different types of cells. These cells include both human cells (mainly erythrocytes) and non-human cells such as bacteria, fungi, yeasts and viruses. In fact, given a standard $70 \mathrm{~kg}$ human male, there are slightly more bacteria than human cells, being the estimated bacteria/human ratio 1:3 [1]. This collection of microbes that inhabit a human body represent the human microbiota.

In the human body, the gut represents the organ with the largest surface area (approximately $32 \mathrm{~m}^{2}$ ) [2] as well as the one with the highest number of microbes, especially in the colon, where the density of bacterial cells has been estimated at $10^{11}$ to $10^{12}$ per milliliter [3]. 
After a child reaches the age of three, the bacterial composition of gut microbiota remains reasonably stable and is unique to everyone depending on different factors like genetics, diet, and different environmental factors. A healthy gut microbiota is characterized by its richness and diversity in its composition [4]. Nevertheless, studies have shown that the normal gut microbiota comprises mainly Bacteroidetes and Firmicutes as the dominant phyla, followed by Actinobacteria and Verrucomicrobia. These gut commensals play an important role in specific functions like nutrient and drug metabolism, protection against pathogens, maintenance of structural integrity of gut mucosal barrier, among others $[5,6]$.

During the last years, a substantial number of studies on the impact of gut microbiota and host health have been conducted, showing that the disruption of gut microbiota homeostasis (called dysbiosis) is related to a large array of diseases. These include metabolic diseases like obesity and metabolic-associated fatty liver disease $[7,8]$, irritable bowel syndrome [9] as well as several immune-related diseases like allergies [10], autoimmune diseases [11], and inflammatory bowel disease [12]. These latter associations illustrate the direct interaction between gut microbiota and the immune system.

Mounting evidence based on humans and rodent models, mainly germ-free mice, support the idea that the gut microbiota is in constant crosstalk with the immune system [13,14]. The immune system is a complex network that includes molecules, cells, tissues, and organs that defend the body against infectious agents and malignant cells. It is broadly divided into innate and adaptive immune systems. The innate immunity response is not specific for any pathogen, and its cells (i.e., natural killer cells, neutrophils, monocytes/macrophages and dendritic cells) express pathogen recognition receptors (PRRs), such as Toll-like receptors (TLRs), that recognize pathogen-associated molecular patterns (PAMPs) that are part of many microorganisms but not of the host body's own cells (Figure 1A). On the other hand, the adaptive immune system can be subdivided into cell-mediated immunity, carried out by $\mathrm{T}$ cells, and humoral immunity (B-cells responses). $\mathrm{T}$ cells expressing the $\mathrm{CD} 4 \mathrm{~T}$ cell co-receptor, called T helper cells, are involved in the activation and maturation of monocytes, cytotoxic T cells (expressing the CD8 T cell co-receptor) and B cells. Cytotoxic $\mathrm{T}$ cells eliminate cancer cells and intracellular pathogens. B cells mature into plasma cells that produce antibodies (immunoglobulins, Ig), eliminating extracellular microorganisms and preventing the spread of infection $[15,16]$ (Figure 1A). Both the innate and the adaptive immune system influences and shapes the composition and diversity of the gut microbiota [17], whereas the gut microbiota modulates the immune system via different metabolites and activation of TLRs signaling pathways [18].

Maintaining gut homeostasis-beneficial microbiota composition-plays a critical role in immune responses. By fermentation of complex carbohydrates, anaerobic bacteria in the gut produce short-chain-fatty acids (SCFAs), which are essential for modulation and mediation of the immune system. SCFAs produced in the gut are mainly butyrate, propionate and acetate and have many different targets and functions in the host organism. SCFAs regulate local immune response in the gut, as well as they act as important immune mediators in extra-intestinal organs such as the brain and the liver as well as in other tissues (for example, skin, lungs and pancreas) [19]. 


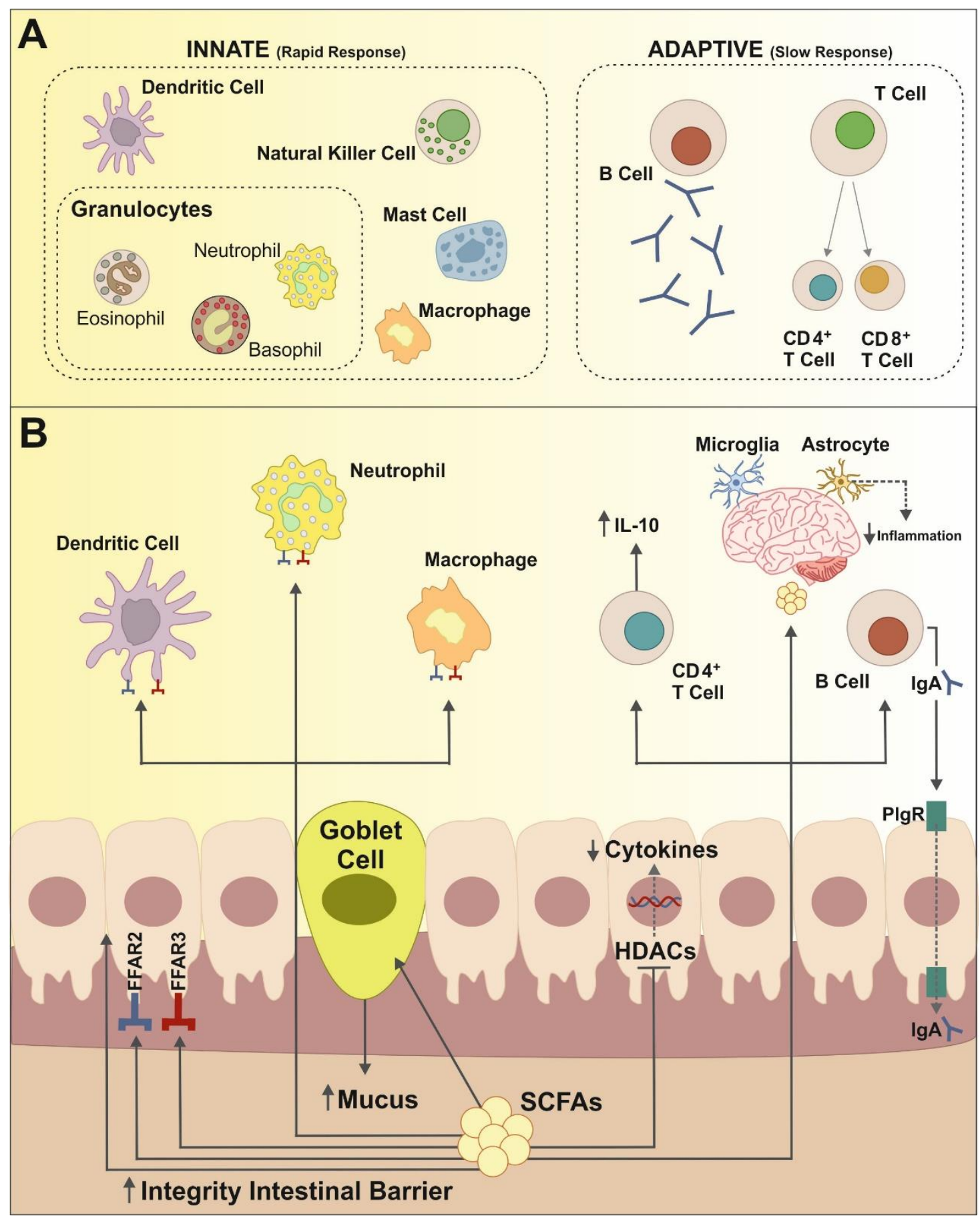

Figure 1. Relationships between the innate and the adaptive immune systems and gut microbiota. (A) The innate immune response is a very fast, pathogen-non-specific, first line of defense mechanism. It is mainly composed of macrophages, dendritic and natural killer cells, as well as different forms of granulocytes. The adaptive immune system is highly specific to a particular pathogen and is formed by B and T cells lymphocytes. (B) The gut microbiota is in close interaction with both the innate and the adaptive immune system. This interaction is frequently driven by SCFAs, which modulate local as well as systemic immune response. SCFAs can bind to G-protein-coupled receptors as FFAR2 and FFAR3 present on the surface of gut epithelial cells and immune cells including dendritic cells, macrophages and neutrophils, and are therefore important regulators of inflammatory response. SCFAs also promote the activation of B cells and the development of Treg CD4+T cells-for example, increasing secretion of IL-10 with important anti-inflammatory effects. Suppression of inflammatory factors like cytokines is further achieved by the inhibition of histone deacetylases (HDACs) activity. Finally, SCFAs have been shown to modulate immune inflammation responses in extraintestinal organs such as the brain, by acting on microglia and astrocytes. 
In the gut, the uptake of SCFAs by intestinal epithelial cells (IECs), mainly butyrate, promotes the integrity of the intestinal barrier, reducing intestinal permeability [20] and, therefore, preventing bacterial translocation through the gut wall and the resulting endotoxemia and associated immune response [17]. SCFAs also exhibits important antiinflammatory effects on gut immune cells. For example, butyrate stimulated differentiation of T-regulatory cells and increased levels of IL-10 while reducing production of IL-6 and inhibiting the expansion of pro-inflammatory Th17 cells [21]. Moreover, SCFAs show epigenetic regulatory effects by inhibiting HDACS promoting in this way the suppression of inflammatory responses in immune cells $[22,23]$ as well as promoting production of IgA and IgG antibodies by B cells. SCFAs have also shown to be natural ligands for free fatty acid receptor 2 and 3 (FFAR 2 and FFAR 3 also known as GPR43 and GPR41, respectively) [24]. In particular, FFAR2 are highly related to immune cell function and mast cell activity since they are expressed in neutrophils, macrophages and dendritic cells, among others (Figure 1B). Activation of FFAR2 has been associated with the maintenance of gut homeostasis and regulation of inflammation related to disease such as asthma, allergies, cardiovascular and fatty-liver disease [25].

SCFAs have been associated with normal development of brain resident immune cells, specifically with microglia and astrocytes. In the brain, microglia are the most abundant immune cells and perform a variety of functions including phagocytosis, cytokine production and activation of inflammatory response, between others [26]. As observed in germ-free mice as well as in animals presenting FFAR2 abnormalities, alterations in gut microbiota lead to abnormal microglial abundance, morphology, and gene expression patterns $[27,28]$. Astrocytes, on the other hand, are the most frequent glial cells in the brain and perform several immune related functions including the expression of pattern recognition receptors for detection of microbial-associated molecular pattern (MAMPs) and modulation of the neuroinflammatory response [29]. Metabolites produced in the gut by metabolization of dietary tryptophan are able to bind to astrocyte aryl hydrocarbon receptors (AHR) reducing by this way proinflammatory factors (Figure 1B). Therefore, intestinal bacteria seem to be an important regulator of neuroinflammation. This idea has been supported by different studies using a mouse model of multiple sclerosis (called experimental autoimmune encephalomyelitis, EAE) showing a protective effect of SCFAs by increasing IL-10 producing regulatory T cells differentiation. Altogether, this interaction between gut microbiota and immune system on the gut-brain axis plays an important role in the etiopathogenesis of psychiatric and neurological diseases such as autism spectrum disorder, depression and addiction, among others [13,30].

The interaction between the liver immune system and the microbiome, under normal health conditions, is limited. Only select substances can cross the intestinal barrier and move into the liver, the bile ducts and the portal vein being the major connection points between the liver and microbiome [31]. However, in certain contexts, when intestinal commensals and their products translocate from the intestinal lumen to the liver, hepatic immune responses may be affected [32]. For example, the number, functional activity, and maturational status of the hepatic Kupffer cells (KCs), a critical component of the hepatic innate immune system, are directly related to the concentration of gut-derived MAMPs [33]. Intestinal pathogenic bacteria facilitate immune-mediated liver injury by activating dendritic cells (DCs) and natural killer T (NKT) cells in the liver [34]. Additionally, it has been reported that probiotics may contain bacterial glycolipid antigens that stimulate hepatic NKT cells in a strain-specific and dose dependent manner [35].

\section{Effects of Alcohol on Gut Microbiota}

Alcohol addiction is a leading risk factor for personal death and disability. In 2016, the harmful use of alcohol resulted in some 3 million deaths (5.3\% of all deaths) worldwide and 132.6 million disability-adjusted life years (DALYs), i.e., 5.1\% of all DALYs in that year. Among men in 2016, an estimated 2.3 million deaths and 106.5 million DALYs were 
attributable to the consumption of alcohol. Women experienced 0.7 million deaths and 26.1 million DALYs attributable to alcohol consumption [36].

Alcohol abuse represents a risk factor for liver diseases, such as alcoholic steatohepatitis and cirrhosis [37] in such a way that approximately $25 \%$ of heavy drinkers develop clinically alcoholic liver disease (ALD).

Although alcohol is absorbed through the mucosa of the entirely gastrointestinal tract by simple diffusion, it is mainly absorbed in the upper part of the tract [38], the majority of it (70\%) in the small intestine [39]. The large part of alcohol metabolism in humans occurs in the hepatocytes, main cells of the liver. Ethanol is metabolized by alcohol dehydrogenases (ADH), catalase or cytochrome P450 2E1 to acetaldehyde which is then further oxidized to acetate by aldehyde dehydrogenase (ALDH) [40]. Ninety percent of the moderate alcohol consumed is metabolized through oxidative conversion by alcohol dehydrogenases enzymes while the microsomal ethanol-oxidizing system (MEOS) handles the remaining $10 \%$; this last route acquires greater importance when alcohol consumption increases significantly. MEOS leads to the production of oxygen free radicals, which can cause cellular damage [41]. Besides in the liver, the enzymes involved in the oxidative metabolism of alcohol also are present in the intestinal mucosa and intestinal bacteria also produce acetaldehyde in the gastrointestinal tract [41].

The intestinal microbiota (IMB) is the set of microorganisms that inhabit our intestines. These microorganisms, among others, include bacteria, fungi, yeasts and viruses [42]. However, in most cases, when referring to IMB, one usually refers to the populations of bacteria that have colonized our large intestine. Gut dysbiosis, which may result in an overgrowth of Gram-negative bacteria [38], can be yielded by the direct toxicity of the alcohol or by indirect mechanisms triggered by alcohol such as the alteration of gut motility [43], the gastric acid output [44], the bile-acid metabolism [45] and an increase in fecal $\mathrm{pH}$ [46].

To date, most studies have reported that heavy alcohol consumption directly alters the biodiversity of gut microbes and produces dramatic change in the relative abundance of some particular microbes, causing dysbiosis and inflammation in the gut [47-49]. Similar effects have been shown in moderate alcohol consumption and chronic consumption in animal models [46,50-52]. Intestinal dysbiosis was correlated with the amount of alcohol consumed [47]. Although the changes are specific to the species studied (rodents or humans) and the alcohol ingestion protocol, there is trend for a depletion of bacteria with anti-inflammatory activity, such as Bacteroidetes and Firmicutes phyla, and an increase in bacteria with pro-inflammation activity, such as Proteobacteria, following alcohol consumption [47-49]. Unlike chronic alcohol consumption, binge drinking pattern (a frequent form of alcohol consumption, defined as 5 or more drinks for men and 4 or more drinks for women within $2 \mathrm{~h}$ ) has not shown homogeneous results even using similar experimental designs. Some studies have found an effect of binge drinking on IMB (increased 16S rDNA levels) [53], but others have obtained negative results [54]; therefore, more studies are needed to elucidate this relationship.

By incompletely understood mechanisms, alcohol abuse leads to a disruption of the intestinal barrier integrity which in combination with the mucosal injury induced by alcohol, increases the permeability of the mucosa [55]. The intestinal barrier is a semipermeable structure that allows the uptake of essential nutrients and immune sensing while being restrictive against pathogenic molecules and bacteria [56]. It is composed of multiple layers of defense that included mucus with antimicrobial peptides and immunoglobulin A molecules, monolayer epithelial cells firmly join by tight junction proteins and the inner lamina propria where the immune cells reside and play an essential role in protecting the intestinal mucosa against invading bacteria [57]. Numerous studies have demonstrated that ethanol, its metabolites, and alterations of the gut microbiome suppress intestinal tight junction protein expression [58-61] producing that the epithelial layer becomes leaky or "permeable". Alcohol increased gut permeability affects mucosal immunity and allows the translocation of bacterial or some critical components of their membrane into the 
bloodstream [47], reaching other organs that can be damaged. LPS (lipopolysaccharide), Gram-negative bacteria membrane main product, and other bacterial metabolites reach the liver via the portal vein where they are enabled to induce the activation of the inflammatory processes. A study in rats has shown that only two weeks of alcohol administration disrupts the intestinal barrier and after two weeks more, liver injury occurs [62]. In the liver, gut-derived molecules interact with the hepatocytes, parenchymal cells, and immune cells causing injuries including hepatic steatosis, hepatitis, fibrosis, cirrhosis, and hepatocellular carcinoma [63].

The liver is not the only organ distant from the gut that has been associated with deleterious effects of intestinal dysbiosis due to alcohol. The brain is also a target of the gut microbiota. In recent years, there has been a growing awareness of the crosstalk between our intestinal bacteria, the central nervous system (CNS) and behavior [64] (Figure 2).

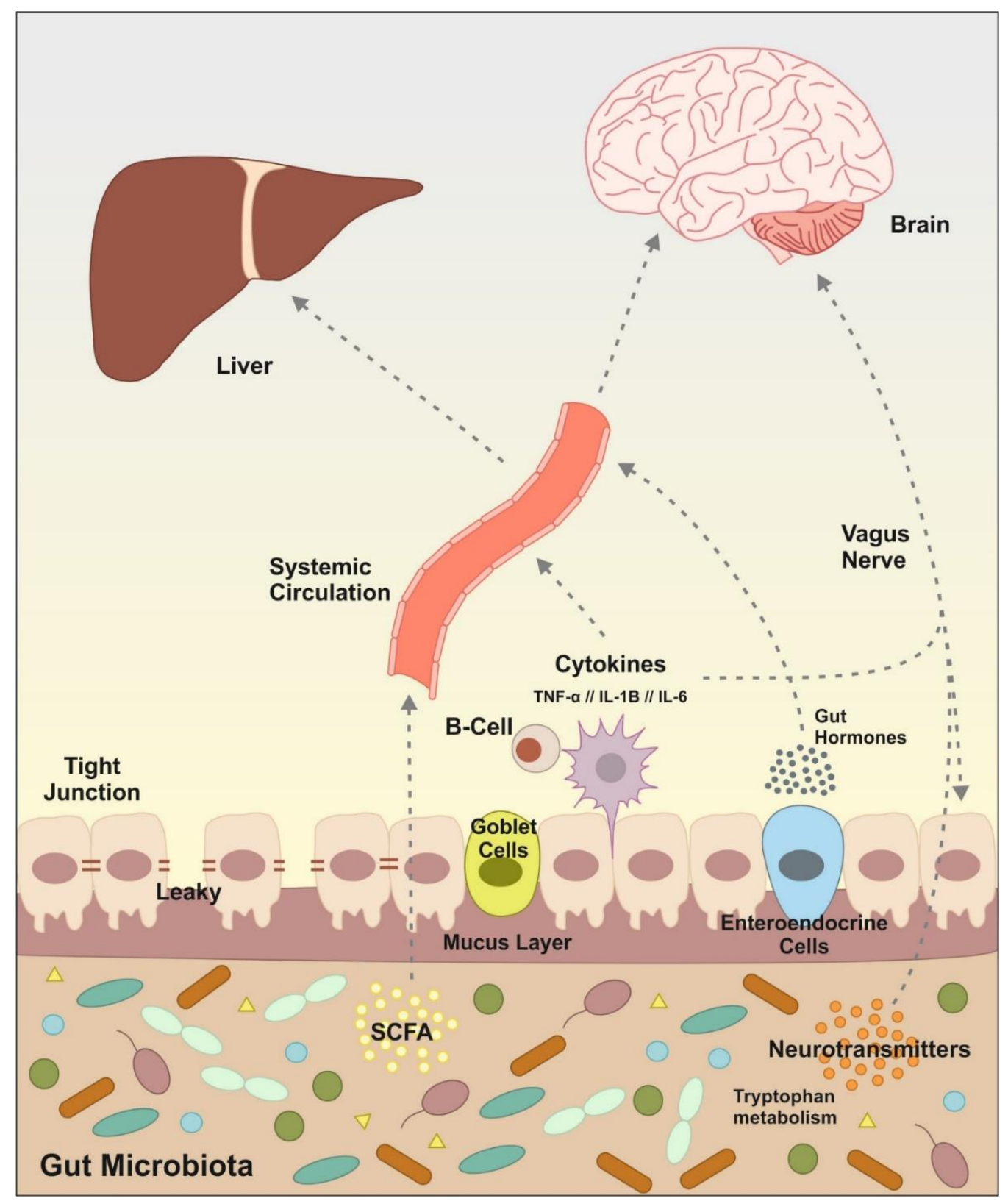

Figure 2. Principal signaling pathway and molecules involved in the communication microbiota/gut to the brain and liver. Gut microbiota can signal to the brain and liver through multiple direct and 
indirect mechanisms. Microbiota produces neurotransmitters, tryptophan metabolites, fermentation metabolic by-products such as short-chain fatty acids (SCFAs), the release of cytokines by immune cells and gut hormone signaling. Some of these molecules can activate the vagus nerve or reach the brain and liver via systemic circulation. Alcohol consumption causes dysregulation in the intestinal microbiota, which leads to an alteration in this communication and subsequently causes alterations in brain and liver functions.

Numerous sources of evidence gathered from experiments carried out in rodents show that modifications in the composition of gut microbiota impact in the brain functions and behavioral aspects [65], including the predisposition to high alcohol consumption [66]. Leclercq et al. [67] found a correlation between leaky gut and inflammation with modifications in scores of depression, anxiety and social interactions in alcohol craving. Along the same line, it has been shown that rats replicate several behavioral and biochemical alterations after stool transplantation from patients with depression and anxiety behaviors [68]. In the study of Xiao et al. [52] transplanted microbiota in mice from alcoholic to healthy, developed emotional symptoms, such as anxiety, which occurs during abstinence.

The IMB maintains bidirectional interaction with critical parts of the CNS [68]. The microbiota-gut-brain axis communicate both organs not only through neuronal signals (neurotransmitters), it also depends on endocrine (hormones and gut peptides) and immune signals (cytokines), and microbiota derived metabolites (short-chain fatty acids -SCFAs-, branched chain aminoacids, and peptidoglycans) acting together to regulate host physiology and microbiota composition [64]. Gut microbiota are able to produce various of the aforementioned metabolites that act on enteroendocrine cells, the vagus nerve or by translocation throughout the gut epithelium into the systemic circulation and may have an impact on host physiology.

The vagus nerve is the fastest and most direct route that connects the gut and the brain, it is composed of afferent and efferent fibers [69]. This nerve transmits information from the gastrointestinal, respiratory and cardiovascular systems and gives feed-back to the visceras. Gut-brain signaling occurs primarily via the vagus nerve, vagal afferents sense intestinal molecules, e.g., intestinal hormones, neurotransmitters or bacterial by-products [64]. The alterations of the vagal activity at intestinal level are associated with bacterial overgrowth and bacterial translocation [70]. As observed by Freeman et al. [71] in alcohol withdrawal and during chronic alcohol feeding, there is a dysregulation in vagal signaling that could result in neuroinflammatory processes.

The main products of the fermentation of dietary fiber, SCFAs (acetate, propionate and butyrate principally) are considered as one of the main direct or indirect mediators of microbiota-gut-brain interactions [72]. The highest production of SCFAs occurs in the proximal colon, where they are quickly and efficiently absorbed, since only $10 \%$ of the acids are excreted with the feces [73]. The rest of the SCFAs reach the circulatory system via the superior or inferior mesenteric vein, reaching the brain and crossing the blood-brain barrier thanks to monocarboxylate transporters thus being able to act as signaling molecules between the gut and the brain [74]. IMB metabolic activity can be modified due to chronic alcohol consumption. Specifically, chronic alcohol consumption could reduce the SCFAs count through the reduction in some Firmicutes genera, such as Faecalibacterium and Ruminococcaceae, on which the production of SCFAs depends [75,76]. Furthermore, it has been described that alcohol consumption would also have effects on other microbiota derived metabolites, leading to increases in branched-chain amino acids [77] and peptidoglycans [78]. However, studies showing the effect of alcohol on these microbiota derived metabolites are scarce.

Alcohol alters the composition of the IMB, resulting in an alteration of the amount and type of neuroactive substances produced by the microbiota, which may lead to behavioral alteration [79]. Gut-brain communication is disrupted by alcohol-related immune and gut dysfunction [80]. Alcohol modifies the intestinal microbiota, $\mathrm{pH}$ and permeability of the intestine, causing an increased entry of endotoxins into our CNS and brain, leading to neuroinflammatory processes. 


\section{Effects of Alcohol on Immune System: Putting All the Pieces Together}

Traditionally, it has been described that alcohol acts on the immune system depending on several variables, including consumption pattern. Thus, several studies indicate that light to moderate consumption leads to reduced levels of systemic inflammation or improved responses to vaccines. In contrast, chronic heavy drinking (CHD) is often associated with a deficient immune response $[15,81]$. In this way, this consumption pattern is associated with an increased risk of infection by several viruses [82], and it has been suggested that it may lead to a greater severity and mortality from the recent COVID-19 pandemic [83-85]. In addition, subjects with Alcohol Use Disorders (AUD) show a worse postoperative recovery, a poor response to vaccination or a slower recovery from infections [81]. CHD alters innate and adaptive immune responses [82,86] and can affect a large number of systems through them, since this type of consumption has been associated with damage to different tissues such as pancreas, liver, gut, circulatory system or nervous system [87], and there are several studies that attribute, at least in part, a role of persistent systemic and local inflammation in these conditions [88].

Some of the effects of CHD on cells of the immune system include reduction in Tcell numbers, loss of naïve T-cells, increased CD8+ T-cell activation and proliferation, or alterations in monocytes $[81,89]$. Together with the effect of alcohol consumption on Toll-like receptors [90-92], one of the most reported data are the upregulation of several cytokines after alcohol administration [93]. In fact, a recent meta-analysis [94] studied the differences in cytokine patterns presented by subjects with AUD and concluded that they show a higher concentration of cytokines than control patients. Furthermore, these authors found clear differences depending on the different stages of AUD illness: active drinking, withdrawal and various periods of abstinence. Such results are very interesting in order to develop potential biomarkers of alcohol consumption [95], as well as pharmacological alternatives to treat alcoholism [96]. Although the effect of alcohol on the immune system occurs at the systemic level and affects various organs, we will focus on the effect of this substance on the gut, brain and liver (Figure 3), due to the importance of these organs in the relationship between alcohol consumption, intestinal microbiota and the immune system [97].

The gut is the largest organ with immune function in our body [98] and, in order to regulate the immune response, the gut must keep the homeostasis of the intestinal barrier in check $[99,100]$. As mentioned above, alcohol consumption increases intestinal permeability through the suppression of intestinal tight junction protein expression. This alteration allows the translocation of bacterial products to the systemic circulation. The gut-derived bacterial components together with LPS activate the immune cells localized in the systemic circulation (peripheral blood mononuclear cells), or in target organs [101]. The release of LPS into the bloodstream results in the activation of two important targets of the immune response: TLR4 and nucleotide-binding domain leucine-rich repeat containing 3 (NLRP3) or cryopyrin. In that sense, research on the role of TLRs in the pathogenesis of alcoholism has revealed that these receptors mediate the development of a neuroinflammatory effect in the CNS derived from alcohol consumption [102,103].

The activity of these receptors triggers the activation of a number of molecular pathways that result in the expression of genes of the innate immune system, mainly proinflammatory factors, that contribute to a permanent neuroinflammatory state of the CNS. A study conducted in 2015 showed that blocking TLR4 function most of the neuroinflammatory effects produced by ethanol were diminished [104]. In another study, adolescent mice that consumed ethanol intermittently $(3 \mathrm{~g} / \mathrm{kg})$ for two weeks, showed that this consumption pattern leads to an activation of TLR4 signaling pathways, an up-regulation of cytokines and proinflammatory mediators, in addition to synaptic and myelin alterations. TLR4-deficient mice prevented such neuroinflammation, synaptic and myelin alterations, as well as long-term cognitive alterations [105]. 


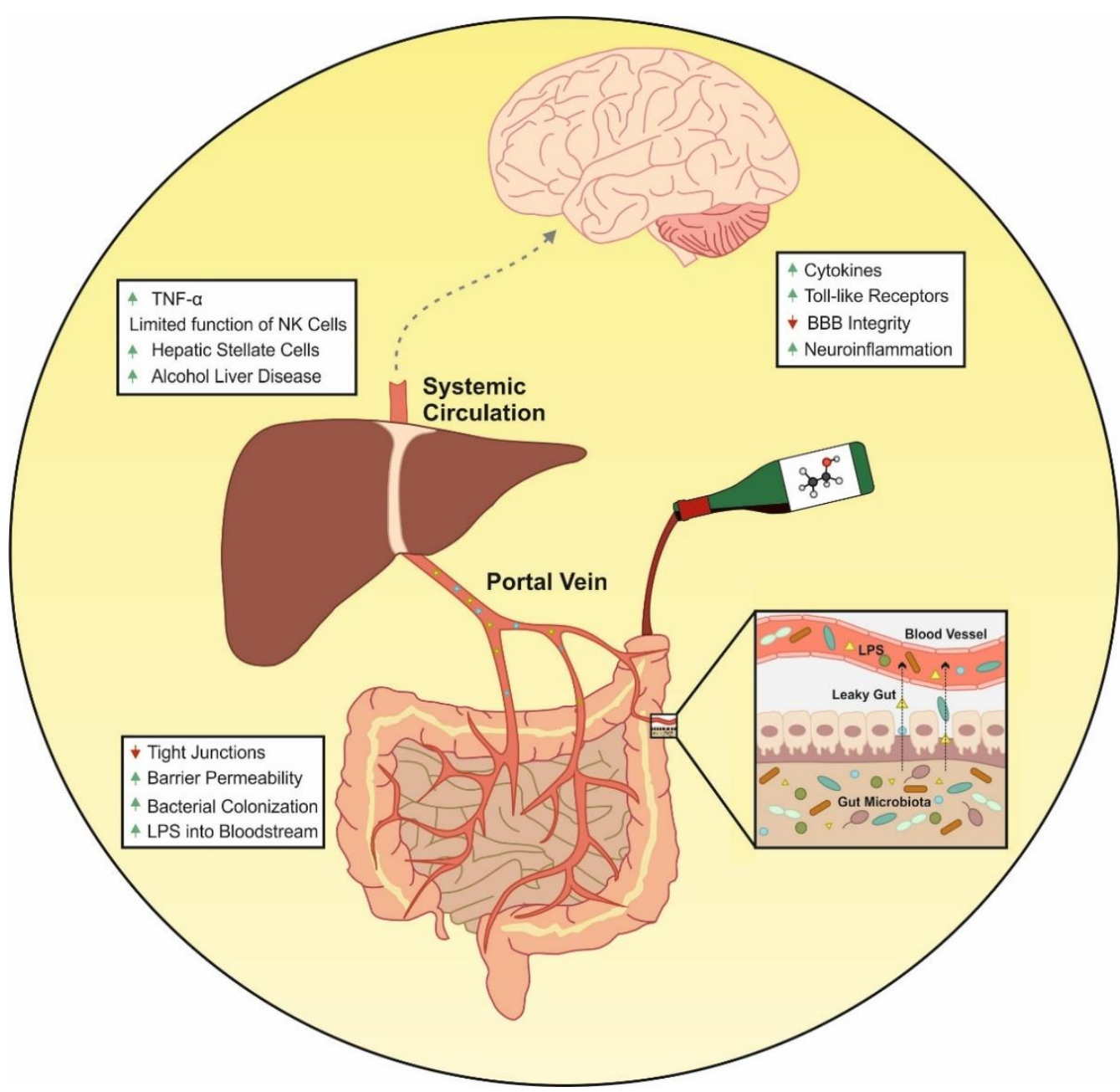

Figure 3. Effects of alcohol on the immune system. Alcohol consumption increases intestinal permeability through the suppression of intestinal tight junction protein expression. This alteration allows the translocation of bacterial products to the systemic circulation. The gut-derived bacterial components together with LPS activate the immune cells localized in the systemic circulation or in target organs such as liver and brain. This causes the increase in pro-inflammatory components that can lead to alcohol liver disease or increased states of neuroinflammation.

Interestingly, in addition to supporting neuroinflammation, TLR signaling is likely engaged in the mechanisms of regulation of the functional activity of neurotransmitter systems, which may contribute to the formation of a pathological demand for alcohol [106]. Together with TLRs activation, the production of cytokines, which can cross the blood-brain barrier (BBB), have harmful effects at CNS level [102]. To that respect, the BBB is known to be a major target for alcohol. Long-term consumption produces serious impairments in the BBB permeability and integrity since alcohol inhibits the expression of BBB structural and functional proteins, promoting inflammation and oxidative stress [107].

The immune response, therefore, would be one of the main channels through which the gut-brain axis establishes communication [108]. Since alcohol is responsible for inducing changes in this communication, leading to peripheral and central inflammation [109], dysfunction in gut microbiota and the subsequent affection of the immune system is linked to the development of mental illnesses, brain dysfunction and neurodegenerative disorders like Alzheimer's and Parkinson's diseases [110-113]. Interestingly, central neuroinflammation is maintained after cessation of alcohol consumption, compared to peripheral activation [114] and during periods of abstinence [108]. Finally, in relation to the effect of alcohol on neuroinflammation, a study by Lowe et al. showed an attenuation of alcohol- 
induced neuroinflammation after reducing the gut bacterial load, as a result of antibiotic treatment [115]. We could hypothesize that by reducing the gut bacterial load, lower amounts of bacterial components would reach the systemic circulation, leading to reduced activation of pro-inflammatory components.

In addition to the central inflammatory effect, $\mathrm{CHD}$ induces a peripheral inflammatory response that plays an important role in the development of alcoholic liver disease (ALD) [108]. ALD is a broad term that refers to a variety of liver ailments. In particular, numerous clinical and experimental research [116-120] have revealed the role of immunology in fueling inflammation and progression of ALD. As said before, alcohol consumption modifies the barrier function of the intestinal mucosa, leading to an increased bacterial load together with high levels of LPS that enters the portal circulation through alcohol-disrupted barrier of gut. LPS activates innate immunity via TLRs expressed by immune cells producing immunological challenges that disrupt the liver's finely tuned immune pathways [121-123]. Some other cellular sensors of pathogen- or damage-associated molecular patterns (PAMPs/DAMPs) are further activated, leading to the generation of pro-inflammatory cytokines like TNF- $\alpha$ and ILs, which contributes to ALD [123]. Both innate and adaptive immunity are known to have a role in the pathogenesis of ALD [124]. As a result of continued alcohol misuse, alcoholic hepatitis and fibrosis develop. At this point, the oxidative breakdown of alcohol limits the function of immune cells like natural killer (NK) cells, which cause activated hepatic stellate cells (HSCs) to enter in apoptosis, resulting in mild fibrosis [125-127]. Finally, fibrotic distortion of tissues and blood vessels, as well as cell necrosis, characterize the ultimate stage of ALD. The failure of the liver to eliminate microbial and other circulating pro-inflammatory chemicals, as well as the release of immunogenic cellular debris from necrotic hepatocytes, results in prolonged immune system activation and worsens the condition [128,129].

\section{Conclusions}

Chronic excessive alcohol consumption causes inflammation in a variety of organs, including the gut, brain and liver. While alcohol has direct effects on the gastrointestinal tract when it comes into touch with the mucosa, the majority of alcohol's biological effects are due to its systemic dispersion and delivery through the blood. Alcohol has been proven to affect the microbiome in the gastrointestinal tract, with alcoholics having a different and higher bacterial load in their gut. Once the integrity of the gut mucosa is impaired, LPS enters the portal circulation contributing to enhance the inflammatory changes in other organs such liver and brain.

Author Contributions: J.A.L.-M. conceived and designed the manuscript. J.C.-C. and V.E.-A. prepared the figures. All authors have equally participated in searching for information and writing the manuscript. All authors have read and agreed to the published version of the manuscript.

Funding: This work was supported by National Plan on Drug Abuse, Ministerio de Sanidad of Spain (grant PNSD2018-050 to J.A.L.M.), the Fondo de Investigación Sanitaria (Red de Trastornos Adictivos, FEDER, RD16/0017/0008 to J.A.L.M.; RD16/0017/0001 to F.R.D.F.) and the Instituto de Salud Carlos III (Sara Borrell research contract CD17/00125 to V.E.A.).

Institutional Review Board Statement: Not applicable.

Informed Consent Statement: Not applicable.

Data Availability Statement: Not applicable.

Conflicts of Interest: The authors declare no conflict of interest.

\section{References}

1. Sender, R.; Fuchs, S.; Milo, R. Revised Estimates for the Number of Human and Bacteria Cells in the Body. PLoS Biol. 2016, 14, e1002533. [CrossRef] [PubMed]

2. Helander, H.F.; Fändriks, L. Surface area of the digestive tract revisited. Scand. J. Gastroenterol. 2014, 49, 681-689. [CrossRef] 
3. Ley, R.E.; Turnbaugh, P.J.; Klein, S.; Gordon, J.I. Microbial ecology: Human gut microbes associated with obesity. Nature 2006, 444, 1022-1023. [CrossRef]

4. Rinninella, E.; Raoul, P.; Cintoni, M.; Franceschi, F.; Miggiano, G.A.D.; Gasbarrini, A.; Mele, M.C. What is the Healthy Gut Microbiota Composition? A Changing Ecosystem across Age, Environment, Diet, and Diseases. Microorganisms 2019, 7, 14. [CrossRef] [PubMed]

5. Lynch, S.V.; Pedersen, O. The Human Intestinal Microbiome in Health and Disease. N. Engl. J. Med. 2016, 375, 2369-2379. [CrossRef]

6. Jandhyala, S.M.; Talukdar, R.; Subramanyam, C.; Vuyyuru, H.; Sasikala, M.; Nageshwar Reddy, D. Role of the normal gut microbiota. World J. Gastroenterol. 2015, 21, 8787-8803. [CrossRef] [PubMed]

7. Rampelli, S.; Guenther, K.; Turroni, S.; Wolters, M.; Veidebaum, T.; Kourides, Y.; Molnár, D.; Lissner, L.; Benitez-Paez, A.; Sanz, Y.; et al. Pre-obese children's dysbiotic gut microbiome and unhealthy diets may predict the development of obesity. Commun. Biol. 2018, 1, 222. [CrossRef]

8. Hernández-Ceballos, W.; Cordova-Gallardo, J.; Mendez-Sanchez, N. Gut Microbiota in Metabolic-associated Fatty Liver Disease and in Other Chronic Metabolic Diseases. J. Clin. Transl. Hepatol. 2021, 9, 227-238.

9. Ancona, A.; Petito, C.; Iavarone, I.; Petito, V.; Galasso, L.; Leonetti, A.; Turchini, L.; Belella, D.; Ferrarrese, D.; Addolorato, G.; et al. The gut-brain axis in irritable bowel syndrome and inflammatory bowel disease. Dig. Liver Dis. 2021, 53, 298-305. [CrossRef]

10. Han, P.; Gu, J.Q.; Li, L.S.; Wang, X.Y.; Wang, H.T.; Wang, Y.; Chang, C.; Sun, J.L. The Association Between Intestinal Bacteria and Allergic Diseases-Cause or Consequence? Front. Cell Infect. Microbiol. 2021, 11, 650893. [CrossRef]

11. Gladman, D.D.; Ibañez, D.; Urowitz, M.B. Systemic lupus erythematosus disease activity index 2000. J. Rheumatol. 2002, 29, 288-291.

12. Aldars-García, L.; Chaparro, M.; Gisbert, J.P. Systematic Review: The Gut Microbiome and Its Potential Clinical Application in Inflammatory Bowel Disease. Microorganisms 2021, 9, 977. [CrossRef]

13. Fung, T.C.; Olson, C.A.; Hsiao, E.Y. Interactions between the microbiota, immune and nervous systems in health and disease. Nat. Neurosci. 2017, 20, 145-155. [CrossRef]

14. Yoo, J.Y.; Groer, M.; Dutra, S.V.O.; Sarkar, A.; McSkimming, D.I. Gut Microbiota and Immune System Interactions. Microorganisms 2020, 8, 1587. [CrossRef]

15. Barr, T.; Helms, C.; Grant, K.; Messaoudi, I. Opposing effects of alcohol on the immune system. Prog. Neuropsychopharmacol. Biol. Psychiatry 2016, 65, 242-251. [CrossRef]

16. Murphy, K.; Weaver, C. Janeway's Immunobiology, 9th ed.; Garland Science: New York, NY, USA, 2017.

17. Konturek, P.C.; Harsch, I.A.; Konturek, K.; Schink, M.; Konturek, T.; Neurath, M.F.; Zopf, Y. Gut-Liver Axis: How Do Gut Bacteria Influence the Liver? Med. Sci. 2018, 6, 79. [CrossRef]

18. Fan, Y.; Li, Y.; Chu, Y.; Liu, J.; Cui, L.; Zhang, D. Toll-Like Receptors Recognize Intestinal Microbes in Liver Cirrhosis. Front. Immunol. 2021, 12, 608498. [CrossRef] [PubMed]

19. Silva, Y.P.; Bernardi, A.; Frozza, R.L. The Role of Short-Chain Fatty Acids From Gut Microbiota in Gut-Brain Communication. Front. Endocrinol. 2020, 11, 25. [CrossRef] [PubMed]

20. Peng, L.; Li, Z.R.; Green, R.S.; Holzman, I.R.; Lin, J. Butyrate enhances the intestinal barrier by facilitating tight junction assembly via activation of AMP-activated protein kinase in Caco-2 cell monolayers. J. Nutr. 2009, 139, 1619-1625. [CrossRef] [PubMed]

21. Chen, L.; Sun, M.; Wu, W.; Yang, W.; Huang, X.; Xiao, Y.; Ma, C.; Xu, L.; Yao, S.; Liu, Z.; et al. Microbiota Metabolite Butyrate Differentially Regulates Th1 and Th17 Cells' Differentiation and Function in Induction of Colitis. Inflamm. Bowel. Dis. 2019, 25, 1450-1461. [CrossRef] [PubMed]

22. Kasubuchi, M.; Hasegawa, S.; Hiramatsu, T.; Ichimura, A.; Kimura, I. Dietary gut microbial metabolites, short-chain fatty acids, and host metabolic regulation. Nutrients 2015, 7, 2839-2849. [CrossRef]

23. Ratajczak, W.; Rył, A.; Mizerski, A.; Walczakiewicz, K.; Sipak, O.; Laszczyńska, M. Immunomodulatory potential of gut microbiome-derived short-chain fatty acids (SCFAs). Acta Biochim. Pol. 2019, 66, 1-12. [CrossRef]

24. Kaemmerer, E.; Plum, P.; Klaus, C.; Weiskirchen, R.; Liedtke, C.; Adolf, M.; Schippers, A.; Wagner, N.; Reinartz, A.; Gassler, N. Fatty acid binding receptors in intestinal physiology and pathophysiology. World J. Gastrointest. Pathophysiol. 2010, 1, 147-153. [CrossRef] [PubMed]

25. Tan, J.K.; McKenzie, C.; Mariño, E.; Macia, L.; Mackay, C.R. Metabolite-Sensing G Protein-Coupled Receptors-Facilitators of Diet-Related Immune Regulation. Annu. Rev. Immunol. 2017, 35, 371-402. [CrossRef]

26. Graeber, M.B.; Li, W.; Rodriguez, M.L. Role of microglia in CNS inflammation. FEBS Lett. 2011, 585, 3798-3805. [CrossRef] [PubMed]

27. Mossad, O.; Erny, D. The microbiota-microglia axis in central nervous system disorders. Brain Pathol. 2020, 30, 1159-1177. [CrossRef] [PubMed]

28. Erny, D.; Prinz, M. How microbiota shape microglial phenotypes and epigenetics. Glia 2020, 68, 1655-1672. [CrossRef]

29. Zhao, Y.F.; Wei, D.N.; Tang, Y. Gut microbiota regulate astrocytic functions in the brain: Possible therapeutic consequences. Curr. Neuropharmacol. 2021. [CrossRef]

30. Leclercq, S.; Stärkel, P.; Delzenne, N.M.; de Timary, P. The gut microbiota: A new target in the management of alcohol dependence? Alcohol 2019, 74, 105-111. [CrossRef] 
31. Bruellman, R.; Llorente, C. A Perspective of Intestinal Immune-Microbiome Interactions In Alcohol-Associated Liver Disease. Int. J. Biol. Sci. 2021, 17, 307-327. [CrossRef]

32. Zheng, D.; Liwinski, T.; Elinav, E. Interaction between microbiota and immunity in health and disease. Cell Res. 2020, 30, 492-506. [CrossRef]

33. Corbitt, N.; Kimura, S.; Isse, K.; Specht, S.; Chedwick, L.; Rosborough, B.R.; Lunz, J.G.; Murase, N.; Yokota, S.; Demetris, A.J. Gut bacteria drive Kupffer cell expansion via MAMP-mediated ICAM-1 induction on sinusoidal endothelium and influence preservation-reperfusion injury after orthotopic liver transplantation. Am. J. Pathol. 2013, 182, 180-191. [CrossRef]

34. Chen, J.; Wei, Y.; He, J.; Cui, G.; Zhu, Y.; Lu, C.; Ding, Y.; Xue, R.; Bai, L.; Uede, T.; et al. Natural killer T cells play a necessary role in modulating of immune-mediated liver injury by gut microbiota. Sci. Rep. 2014, 4, 7259. [CrossRef]

35. Liang, S.; Webb, T.; Li, Z. Probiotic antigens stimulate hepatic natural killer T cells. Immunology 2014, 141, 203-210. [CrossRef]

36. WHO. Global Status Report on Alcohol and Health; World Health Organization: Geneva, Switzerland, 2016. Available online: https:/ / www.who.int/publications/i/item/9789241565639 (accessed on 15 June 2021).

37. McCullough, A.J.; O'Shea, R.S.; Dasarathy, S. Diagnosis and management of alcoholic liver disease. J. Dig. Dis. 2011, 12, 257-262. [CrossRef]

38. Bode, C.; Bode, J.C. Effect of alcohol consumption on the gut. Best Pract. Res. Clin. Gastroenterol. 2003, 17, 575-592. [CrossRef]

39. Levitt, M.D.; Li, R.; DeMaster, E.G.; Elson, M.; Furne, J.; Levitt, D.G. Use of measurements of ethanol absorption from stomach and intestine to assess human ethanol metabolism. Am. J. Physiol. 1997, 273, G951-7. [CrossRef] [PubMed]

40. Na, H.K.; Lee, J.Y. Molecular Basis of Alcohol-Related Gastric and Colon Cancer. Int. J. Mol. Sci. 2017, $18,1116$.

41. Cederbaum, A.I. Alcohol metabolism. Clin. Liver Dis. 2012, 16, 667-685. [CrossRef] [PubMed]

42. Lloyd-Price, J.; Abu-Ali, G.; Huttenhower, C. The healthy human microbiome. Genome Med. 2016, 8, 51. [CrossRef] [PubMed]

43. Addolorato, G.; Capristo, E.; Gasbarrini, G.; Stefanini, G.F. Depression, alcohol abuse and orocaecal transit time. Gut 1997, 41, 417-418. [CrossRef]

44. Kölbel, C.B.; Singer, M.V.; Möhle, T.; Heinzel, C.; Eysselein, V.; Goebell, H. Action of intravenous ethanol and atropine on the secretion of gastric acid, pancreatic enzymes, and bile acids and the motility of the upper gastrointestinal tract in nonalcoholic humans. Pancreas 1986, 1, 211-218. [CrossRef] [PubMed]

45. Schnabl, B.; Brenner, D.A. Interactions between the intestinal microbiome and liver diseases. Gastroenterology 2014, 146, 1513-1524. [CrossRef]

46. Bull-Otterson, L.; Feng, W.; Kirpich, I.; Wang, Y.; Qin, X.; Liu, Y.; Gobejishvili, L.; Joshi-Barve, S.; Ayvaz, T.; Petrosino, J.; et al. Metagenomic analyses of alcohol induced pathogenic alterations in the intestinal microbiome and the effect of Lactobacillus rhamnosus GG treatment. PLoS ONE 2013, 8, e53028. [CrossRef]

47. Leclercq, S.; Matamoros, S.; Cani, P.D.; Neyrinck, A.M.; Jamar, F.; Stärkel, P.; Windey, K.; Tremaroli, V.; Bäckhed, F.; Verbeke, K.; et al. Intestinal permeability, gut-bacterial dysbiosis, and behavioral markers of alcohol-dependence severity. Proc. Natl. Acad. Sci. USA 2014, 111, E4485-E4493. [CrossRef] [PubMed]

48. Yan, A.W.; Fouts, D.E.; Brandl, J.; Stärkel, P.; Torralba, M.; Schott, E.; Tsukamoto, H.; Nelson, K.E.; Brenner, D.A.; Schnabl, B. Enteric dysbiosis associated with a mouse model of alcoholic liver disease. Hepatology 2011, 53, 96-105. [CrossRef] [PubMed]

49. Mutlu, E.A.; Gillevet, P.M.; Rangwala, H.; Sikaroodi, M.; Naqvi, A.; Engen, P.A.; Kwasny, M.; Lau, C.K.; Keshavarzian, A. Colonic microbiome is altered in alcoholism. Am. J. Physiol. Gastrointest. Liver Physiol. 2012, 302, G966-G978. [CrossRef] [PubMed]

50. Engen, P.A.; Green, S.J.; Voigt, R.M.; Forsyth, C.B.; Keshavarzian, A. The Gastrointestinal Microbiome: Alcohol Effects on the Composition of Intestinal Microbiota. Alcohol Res. 2015, 37, 223-236.

51. Kosnicki, K.L.; Penprase, J.C.; Cintora, P.; Torres, P.J.; Harris, G.L.; Brasser, S.M.; Kelley, S.T. Effects of moderate, voluntary ethanol consumption on the rat and human gut microbiome. Addict. Biol. 2019, 24, 617-630. [CrossRef]

52. Xiao, H.W.; Ge, C.; Feng, G.X.; Li, Y.; Luo, D.; Dong, J.L.; Li, H.; Wang, H.; Cui, M.; Fan, S.J. Gut microbiota modulates alcohol withdrawal-induced anxiety in mice. Toxicol. Lett. 2018, 287, 23-30. [CrossRef]

53. Bala, S.; Marcos, M.; Gattu, A.; Catalano, D.; Szabo, G. Acute binge drinking increases serum endotoxin and bacterial DNA levels in healthy individuals. PLoS ONE 2014, 9, e96864.

54. Stadlbauer, V.; Horvath, A.; Komarova, I. A single alcohol binge impacts on neutrophil function without changes in gut barrier function and gut microbiome composition in healthy volunteers. PLoS ONE 2019, 14, e0211703.

55. Tang, Y.; Zhang, L.; Forsyth, C.B.; Shaikh, M.; Song, S.; Keshavarzian, A. The Role of miR-212 and iNOS in Alcohol-Induced Intestinal Barrier Dysfunction and Steatohepatitis. Alcohol. Clin. Exp. Res. 2015, 39, 1632-1641. [CrossRef]

56. Vancamelbeke, M.; Vermeire, S. The intestinal barrier: A fundamental role in health and disease. Expert Rev. Gastroenterol. Hepatol. 2017, 11, 821-834. [CrossRef] [PubMed]

57. Gallo, R.L.; Hooper, L.V. Epithelial antimicrobial defence of the skin and intestine. Nat. Rev. Immunol. 2012, 12, 503-516. [CrossRef] [PubMed]

58. Chen, P.; Stärkel, P.; Turner, J.R.; Ho, S.B.; Schnabl, B. Dysbiosis-induced intestinal inflammation activates tumor necrosis factor receptor I and mediates alcoholic liver disease in mice. Hepatology 2015, 61, 883-894. [CrossRef] [PubMed]

59. Mir, H.; Meena, A.S.; Chaudhry, K.K.; Shukla, P.K.; Gangwar, R.; Manda, B.; Padala, M.K.; Shen, L.; Turner, J.R.; Dietrich, P.; et al. Occludin deficiency promotes ethanol-induced disruption of colonic epithelial junctions, gut barrier dysfunction and liver damage in mice. Biochim. Biophys. Acta 2016, 1860, 765-774. [CrossRef] [PubMed] 
60. Samak, G.; Gangwar, R.; Meena, A.S.; Rao, R.G.; Shukla, P.K.; Manda, B.; Narayanan, D.; Jaggar, J.H.; Rao, R. Calcium Channels and Oxidative Stress Mediate a Synergistic Disruption of Tight Junctions by Ethanol and Acetaldehyde in Caco-2 Cell Monolayers. Sci. Rep. 2016, 6, 38899. [CrossRef] [PubMed]

61. Chopyk, D.M.; Kumar, P.; Raeman, R.; Liu, Y.; Smith, T.; Anania, F.A. Dysregulation of junctional adhesion molecule-A contributes to ethanol-induced barrier disruption in intestinal epithelial cell monolayers. Physiol. Rep. 2017, 5, e13541. [CrossRef]

62. Keshavarzian, A.; Farhadi, A.; Forsyth, C.B.; Rangan, J.; Jakate, S.; Shaikh, M.; Banan, A.; Fields, J.Z. Evidence that chronic alcohol exposure promotes intestinal oxidative stress, intestinal hyperpermeability and endotoxemia prior to development of alcoholic steatohepatitis in rats. J. Hepatol. 2009, 50, 538-547. [CrossRef]

63. Stärkel, P.; Leclercq, S.; de Timary, P.; Schnabl, B. Intestinal dysbiosis and permeability: The yin and yang in alcohol dependence and alcoholic liver disease. Clin. Sci. 2018, 132, 199-212. [CrossRef]

64. Cryan, J.F.; O’Riordan, K.J.; Cowan, C.S.M.; Sandhu, K.V.; Bastiaanssen, T.F.S.; Boehme, M.; Codagnone, M.G.; Cussotto, S.; Fulling, C.; Golubeva, A.V.; et al. The Microbiota-Gut-Brain Axis. Physiol. Rev. 2019, 99, 1877-2013. [CrossRef] [PubMed]

65. Bravo, J.A.; Forsythe, P.; Chew, M.V.; Escaravage, E.; Savignac, H.M.; Dinan, T.G.; Bienenstock, J.; Cryan, J.F. Ingestion of Lactobacillus strain regulates emotional behavior and central GABA receptor expression in a mouse via the vagus nerve. Proc. Natl. Acad. Sci. USA 2011, 108, 16050-16055. [CrossRef]

66. Ezquer, F.; Quintanilla, M.E.; Moya-Flores, F.; Morales, P.; Munita, J.M.; Olivares, B.; Landskron, G.; Hermoso, M.A.; Ezquer, M.; Herrera-Marschitz, M.; et al. Innate gut microbiota predisposes to high alcohol consumption. Addict. Biol. 2021, 11, e13018.

67. Leclercq, S.; Cani, P.D.; Neyrinck, A.M.; Stärkel, P.; Jamar, F.; Mikolajczak, M.; Delzenne, N.M.; de Timary, P. Role of intestinal permeability and inflammation in the biological and behavioral control of alcohol-dependent subjects. Brain Behav. Immun. 2012, 26, 911-918. [CrossRef]

68. Kelly, J.R.; Borre, Y.; O’ Brien, C.; Patterson, E.; El Aidy, S.; Deane, J.; Kennedy, P.J.; Beers, S.; Scott, K.; Moloney, G.; et al. Transferring the blues: Depression-associated gut microbiota induces neurobehavioural changes in the rat. J. Psychiatr. Res. 2016, 82, 109-118. [CrossRef] [PubMed]

69. Prechtl, J.C.; Powley, T.L. The fiber composition of the abdominal vagus of the rat. Anat. Embryol. 1990, 181, 101-115. [CrossRef] [PubMed]

70. Van Felius, I.D.; Akkermans, L.M.; Bosscha, K.; Verheem, A.; Harmsen, W.; Visser, M.R.; Gooszen, H.G. Interdigestive small bowel motility and duodenal bacterial overgrowth in experimental acute pancreatitis. Neurogastroenterol. Motil. 2003, 15, 267-276. [CrossRef]

71. Freeman, K.; Brureau, A.; Vadigepalli, R.; Staehle, M.M.; Brureau, M.M.; Gonye, G.E.; Hoek, J.B.; Hooper, D.C.; Schwaber, J.S Temporal changes in innate immune signals in a rat model of alcohol withdrawal in emotional and cardiorespiratory homeostatic nuclei. J. Neuroinflamm. 2012, 9, 97. [CrossRef]

72. Hu, J.; Lin, S.; Zheng, B.; Cheung, P.C.K. Short-chain fatty acids in control of energy metabolism. Crit. Rev. Food Sci. Nutr. 2018, 58, 1243-1249. [CrossRef]

73. Boets, E.; Deroover, L.; Houben, E.; Vermeulen, K.; Gomand, S.V.; Delcour, J.A.; Verbeke, K. Quantification of in Vivo Colonic Short Chain Fatty Acid Production from Inulin. Nutrients 2015, 7, 8916-8929. [CrossRef]

74. Vijay, N.; Morris, M.E. Role of monocarboxylate transporters in drug delivery to the brain. Curr. Pharm. Des. 2014, 20, 1487-1498. [CrossRef]

75. Bjørkhaug, S.T.; Aanes, H.; Neupane, S.P.; Bramness, J.G.; Malvik, S.; Henriksen, C.; Skar, V.; Medhus, A.W.; Valeur, J. Characterization of gut microbiota composition and functions in patients with chronic alcohol overconsumption. Gut Microbes 2019, 10, 663-675. [CrossRef]

76. Lin, R.; Zhang, Y.; Chen, L.; Qi, Y.; He, J.; Hu, M.; Zhang, Y.; Fan, L.; Yang, T.; Wang, L.; et al. The effects of cigarettes and alcohol on intestinal microbiota in healthy men. J. Microbiol. 2020, 58, 926-937. [CrossRef] [PubMed]

77. Melnik, B.C. Dairy consumption and hepatocellular carcinoma risk. Ann. Transl. Med. 2021, 9, 736. [CrossRef] [PubMed]

78. Tabata, T.; Tani, T.; Endo, Y.; Hanasawa, K. Bacterial translocation and peptidoglycan translocation by acute ethanol administration. J. Gastroenterol. 2002, 37, 726-731. [CrossRef] [PubMed]

79. Qamar, N.; Castano, D.; Patt, C.; Chu, T.; Cottrell, J.; Chang, S.L. Meta-analysis of alcohol induced gut dysbiosis and the resulting behavioral impact. Behav. Brain Res. 2019, 376, 112196. [CrossRef]

80. Gorky, J.; Schwaber, J. The role of the gut-brain axis in alcohol use disorders. Prog. Neuropsychopharmacol. Biol. Psychiatry 2016, 65, 234-241. [CrossRef]

81. Sureshchandra, S.; Raus, A.; Jankeel, A.; Ligh, B.J.K.; Walter, N.A.R.; Newman, N.; Grant, K.A.; Messaoudi, I. Dose-dependent effects of chronic alcohol drinking on peripheral immune responses. Sci. Rep. 2019, 9, 7847. [CrossRef] [PubMed]

82. Szabo, G.; Saha, B. Alcohol's Effect on Host Defense. Alcohol. Res. 2015, 37, 159-170. [PubMed]

83. Muhammad, J.S.; Siddiqui, R.; Khan, N.A. COVID-19: Is There a Link between Alcohol Abuse and SARS-CoV-2-Induced Severe Neurological Manifestations? ACS Pharmacol. Transl. Sci. 2021, 4, 1024-1025. [CrossRef] [PubMed]

84. Benzano, D.; Ornell, F.; Schuch, J.B.; Pechansky, F.; Sordi, A.O.; von Diemen, L.; Kessler, F.H.P. Clinical vulnerability for severity and mortality by COVID-19 among users of alcohol and other substances. Psychiatry Res. 2021, 300, 113915. [CrossRef] [PubMed]

85. Calina, D.; Hartung, T.; Mardare, I.; Mitroi, M.; Poulas, K.; Tsatsakis, A.; Rogoveanu, I.; Docea, A.O. COVID-19 pandemic and alcohol consumption: Impacts and interconnections. Toxicol. Rep. 2021, 8, 529-535. [CrossRef]

86. Molina, P.E.; Nelson, S. Binge Drinking's Effects on the Body. Alcohol. Res. 2018, 39, 99-109. [PubMed] 
87. Doggui, R.; Elsawy, W.; Conti, A.A.; Baldacchino, A. Association between chronic psychoactive substances use and systemic inflammation: A systematic review and meta-analysis. Neurosci. Biobehav. Rev. 2021, 125, 208-220. [CrossRef] [PubMed]

88. Lee, J.S.; O'Connell, E.M.; Pacher, P.; Lohoff, F.W. PCSK9 and the Gut-Liver-Brain Axis: A Novel Therapeutic Target for Immune Regulation in Alcohol Use Disorder. J. Clin. Med. 2021, 10, 1758. [CrossRef]

89. García-Calvo, X.; Bolao, F.; Sanvisens, A.; Zuluaga, P.; Tor, J.; Muga, R.; Fuster, D. Significance of Markers of Monocyte Activation (CD163 and sCD14) and Inflammation (IL-6) in Patients Admitted for Alcohol Use Disorder Treatment. Alcohol. Clin. Exp. Res. 2020, 44, 152-158. [CrossRef]

90. Pascual, M.; Baliño, P.; Alfonso-Loeches, S.; Aragón, C.M.; Guerri, C. Impact of TLR4 on behavioral and cognitive dysfunctions associated with alcohol-induced neuroinflammatory damage. Brain Behav. Immun. 2011, 25, S80-S91. [CrossRef]

91. Ibáñez, F.; Montesinos, J.; Ureña-Peralta, J.R.; Guerri, C.; Pascual, M. TLR4 participates in the transmission of ethanol-induced neuroinflammation via astrocyte-derived extracellular vesicles. J. Neuroinflamm. 2019, 16, 136. [CrossRef]

92. Airapetov, M.; Eresko, S.; Lebedev, A.; Bychkov, E.; Shabanov, P. The role of Toll-like receptors in neurobiology of alcoholism. Biosci. Trends 2021, 15, 74-82. [CrossRef]

93. Leclercq, S.; De Saeger, C.; Delzenne, N.; de Timary, P.; Stärkel, P. Role of inflammatory pathways, blood mononuclear cells, and gut-derived bacterial products in alcohol dependence. Biol. Psychiatry 2014, 76, 725-733. [CrossRef]

94. Adams, C.; Conigrave, J.H.; Lewohl, J.; Haber, P.; Morley, K.C. Alcohol use disorder and circulating cytokines: A systematic review and meta-analysis. Brain Behav. Immun. 2020, 89, 501-512. [CrossRef] [PubMed]

95. García-Marchena, N.; Maza-Quiroga, R.; Serrano, A.; Barrios, V.; Requena-Ocaña, N.; Suárez, J.; Chowen, J.A.; Argente, J.; Rubio, G.; Torrens, M.; et al. Abstinent patients with alcohol use disorders show an altered plasma cytokine profile: Identification of both interleukin 6 and interleukin 17A as potential biomarkers of consumption and comorbid liver and pancreatic diseases. J. Psychopharmacol. 2020, 34, 1250-1260. [CrossRef]

96. Calleja-Conde, J.; Fernández-Calle, R.; Zapico, J.M.; Ramos, A.; de Pascual-Teresa, B.; Bühler, K.M.; Echeverry-Alzate, V.; Giné, E.; Rodríguez de Fonseca, F.; López-Moreno, J.A.; et al. Inhibition of Receptor Protein Tyrosine Phosphatase $\beta / \zeta$ Reduces Alcohol Intake in Rats. Alcohol. Clin. Exp. Res. 2020, 44, 1037-1045. [CrossRef]

97. de Timary, P.; Stärkel, P.; Delzenne, N.M.; Leclercq, S. A role for the peripheral immune system in the development of alcohol use disorders? Neuropharmacology 2017, 122, 148-160. [CrossRef]

98. Bain, C.C.; Mowat, A.M. Macrophages in intestinal homeostasis and inflammation. Immunol. Rev. 2014, 260, 102-117. [CrossRef]

99. Abdullah, N.; Defaye, M.; Altier, C. Neural control of gut homeostasis. Am. J. Physiol. Gastrointest. Liver Physiol. 2020, 319, G718-G732. [CrossRef] [PubMed]

100. Glueck, B.; Han, Y.; Cresci, G.A.M. Tributyrin Supplementation Protects Immune Responses and Vasculature and Reduces Oxidative Stress in the Proximal Colon of Mice Exposed to Chronic-Binge Ethanol Feeding. J. Immunol. Res. 2018, 2018, 9671919. [CrossRef]

101. Mandrekar, P.; Szabo, G. Signalling pathways in alcohol-induced liver inflammation. J. Hepatol. 2009, 50, 1258-1266. [CrossRef] [PubMed]

102. Kelley, K.W.; Dantzer, R. Alcoholism and inflammation: Neuroimmunology of behavioral and mood disorders. Brain Behav. Immun. 2011, 25, S13-S20. [CrossRef]

103. Crews, F.T.; Walter, T.J.; Coleman, L.G., Jr.; Vetreno, R.P. Toll-like receptor signaling and stages of addiction. Psychopharmacology 2017, 234, 1483-1498. [CrossRef] [PubMed]

104. Alfonso-Loeches, S.; Ureña-Peralta, J.; Morillo-Bargues, M.J.; Gómez-Pinedo, U.; Guerri, C. Ethanol-Induced TLR4/NLRP3 Neuroinflammatory Response in Microglial Cells Promotes Leukocyte Infiltration Across the BBB. Neurochem. Res. 2016, 41, 193-209. [CrossRef] [PubMed]

105. Montesinos, J.; Pascual, M.; Pla, A.; Maldonado, C.; Rodríguez-Arias, M.; Miñarro, J.; Guerri, C. TLR4 elimination prevents synaptic and myelin alterations and long-term cognitive dysfunctions in adolescent mice with intermittent ethanol treatment. Brain Behav. Immun. 2015, 45, 233-244. [CrossRef]

106. Grantham, E.K.; Warden, A.S.; McCarthy, G.S.; DaCosta, A.; Mason, S.; Blednov, Y.; Mayfield, R.D.; Harris, R.A. Role of toll-like receptor 7 (TLR7) in voluntary alcohol consumption. Brain Behav. Immun. 2020, 89, 423-432. [CrossRef] [PubMed]

107. Wei, J.; Dai, Y.; Wen, W.; Li, J.; Ye, L.L.; Xu, S.; Duan, D.D. Blood-brain barrier integrity is the primary target of alcohol abuse. Chem. Biol. Interact. 2021, 337, 109400. [CrossRef]

108. Salavrakos, M.; Leclercq, S.; De Timary, P.; Dom, G. Microbiome and substances of abuse. Prog. Neuropsychopharmacol. Biol. Psychiatry 2021, 105, 110113. [CrossRef]

109. Wang, H.J.; Zakhari, S.; Jung, M.K. Alcohol, inflammation, and gut-liver-brain interactions in tissue damage and disease development. World J. Gastroenterol. 2010, 16, 1304-1313. [CrossRef] [PubMed]

110. Łuc, M.; Misiak, B.; Pawłowski, M.; Stańczykiewicz, B.; Zabłocka, A.; Szcześniak, D.; Pałęga, A.; Rymaszewska, J. Gut microbiota in dementia. Critical review of novel findings and their potential application. Prog. Neuropsychopharmacol. Biol. Psychiatry 2021, 104, 110039. [CrossRef]

111. Sampson, T.R.; Debelius, J.W.; Thron, T.; Janssen, S.; Shastri, G.G.; Ilhan, Z.E.; Challis, C.; Schretter, C.E.; Rocha, S.; Gradinaru, V.; et al. Gut Microbiota Regulate Motor Deficits and Neuroinflammation in a Model of Parkinson's Disease. Cell 2016, 167, 1469-1480. [CrossRef] 
112. De De-Paula, V.; Forlenza, A.S.; Forlenza, O.V. Relevance of gutmicrobiota in cognition, behaviour and Alzheimer's disease. Pharmacol. Res. 2018, 136, 29-34. [CrossRef] [PubMed]

113. Romano, S.; Savva, G.M.; Bedarf, J.R.; Charles, I.G.; Hildebrand, F.; Narbad, A. Meta-analysis of the Parkinson's disease gut microbiome suggests alterations linked to intestinal inflammation. NPJ Parkinsons. Dis. 2021, 7, 27. [CrossRef] [PubMed]

114. Qin, L.; He, J.; Hanes, R.N.; Pluzarev, O.; Hong, J.S.; Crews, F.T. Increased systemic and brain cytokine production and neuroinflammation by endotoxin following ethanol treatment. J. Neuroinflamm. 2008, 5, 10. [CrossRef] [PubMed]

115. Lowe, P.P.; Gyongyosi, B.; Satishchandran, A.; Iracheta-Vellve, A.; Cho, Y.; Ambade, A.; Szabo, G. Reduced gut microbiome protects from alcohol-induced neuroinflammation and alters intestinal and brain inflammasome expression. J. Neuroinflamm. 2018, 15, 298. [CrossRef] [PubMed]

116. Aguilar-Bravo, B.; Rodrigo-Torres, D.; Ariño, S.; Coll, M.; Pose, E.; Blaya, D.; Graupera, I.; Perea, L.; Vallverdú, J.; Rubio-Tomás, T. Ductular Reaction Cells Display an Inflammatory Profile and Recruit Neutrophils in Alcoholic Hepatitis. Hepatology 2019, 69, 2180-2195. [CrossRef]

117. Saha, B.; Tornai, D.; Kodys, K.; Adejumo, A.; Lowe, P.; McClain, C.; Mitchell, M.; McCullough, A.; Dasarathy, S.; KrollDesrosiers, A. Biomarkers of Macrophage Activation and Immune Danger Signals Predict Clinical Outcomes in Alcoholic Hepatitis. Hepatology 2019, 70, 1134-1149. [CrossRef]

118. Li, W.; Amet, T.; Xing, Y.; Yang, D.; Liangpunsakul, S.; Puri, P.; Kamath, P.S.; Sanyal, A.J.; Shah, V.H.; Katz, B.P.; et al. Alcohol abstinence ameliorates the dysregulated immune profiles in patients with alcoholic hepatitis: A prospective observational study. Hepatology 2017, 66, 575-590. [CrossRef]

119. Byun, J.S.; Yi, H.S. Hepatic Immune Microenvironment in Alcoholic and Nonalcoholic Liver Disease. Biomed. Res. Int. 2017, 2017, 6862439. [CrossRef] [PubMed]

120. Li, S.; Wang, N.; Tan, H.Y.; Hong, M.; Yuen, M.F.; Li, H.; Feng, Y. Expansion of Granulocytic, Myeloid-Derived Suppressor Cells in Response to Ethanol-Induced Acute Liver Damage. Front. Immunol. 2018, 9, 1524. [CrossRef] [PubMed]

121. Iracheta-Vellve, A.; Petrasek, J.; Satishchandran, A.; Gyongyosi, B.; Saha, B.; Kodys, K.; Fitzgerald, K.A.; Kurt-Jones, E.A.; Szabo, G. Inhibition of sterile danger signals, uric acid and ATP, prevents inflammasome activation and protects from alcoholic steatohepatitis in mice. J. Hepatol. 2015, 63, 1147-1455. [CrossRef]

122. Petrasek, J.; Iracheta-Vellve, A.; Saha, B.; Satishchandran, A.; Kodys, K.; Fitzgerald, K.A.; Kurt-Jones, E.A.; Szabo, G. Metabolic danger signals, uric acid and ATP, mediate inflammatory cross-talk between hepatocytes and immune cells in alcoholic liver disease. J. Leukoc. Biol. 2015, 98, 249-256. [CrossRef]

123. Dhanda, A.D.; Collins, P.L. Immune dysfunction in acute alcoholic hepatitis. World J. Gastroenterol. 2015, 21, 11904-11913. [CrossRef]

124. Markwick, L.J.; Riva, A.; Ryan, J.M.; Cooksley, H.; Palma, E.; Tranah, T.H.; Manakkat Vijay, G.K.; Vergis, N.; Thursz, M.; Evans, A.; et al. Blockade of PD1 and TIM3 restores innate and adaptive immunity in patients with acute alcoholic hepatitis. Gastroenterology 2015, 148, 590-602. [CrossRef] [PubMed]

125. Tsuchida, T.; Friedman, S.L. Mechanisms of hepatic stellate cell activation. Nat. Rev. Gastroenterol. Hepatol. $2017,14,397-411$. [CrossRef] [PubMed]

126. Muhanna, N.; Doron, S.; Wald, O.; Horani, A.; Eid, A.; Pappo, O.; Friedman, S.L.; Safadi, R. Activation of hepatic stellate cells after phagocytosis of lymphocytes: A novel pathway of fibrogenesis. Hepatology 2008, 48, 963-977. [CrossRef] [PubMed]

127. Yi, H.S.; Lee, Y.S.; Byun, J.S.; Seo, W.; Jeong, J.M.; Park, O.; Duester, G.; Haseba, T.; Kim, S.C.; Park, K.G.; et al. Alcohol dehydrogenase III exacerbates liver fibrosis by enhancing stellate cell activation and suppressing natural killer cells in mice. Hepatology 2014, 60, 1044-1053. [CrossRef]

128. Barnes, M.A.; Roychowdhury, S.; Nagy, L.E. Innate immunity and cell death in alcoholic liver disease: Role of cytochrome P4502E1. Redox Biol. 2014, 2, 929-935. [CrossRef]

129. Duddempudi, A.T. Immunology in alcoholic liver disease. Clin. Liver Dis. 2012, 16, 687-698. [CrossRef] 